\title{
The City-Level Effects of Offshoring
}

\author{
Perry Burnett ${ }^{1}$, Harvey Cutler ${ }^{2}$ \\ ${ }^{1}$ Department of Economics and Marketing, University of Southern Indiana, Evansville, USA \\ ${ }^{2}$ Department of Economics, Colorado State University, Fort Collins, USA \\ Email: paburnett@usi.edu, harvey.cutler@colostate.edu
}

Received 14 June 2014; revised 12 August 2014; accepted 10 September 2014

Copyright (C) 2014 by authors and Scientific Research Publishing Inc.

This work is licensed under the Creative Commons Attribution International License (CC BY). http://creativecommons.org/licenses/by/4.0/

(c) (7) Open Access

\begin{abstract}
This paper uses a city-level computable general equilibrium (CGE) model to examine the impacts of offshoring for three different periods in the US economy for cities that did not lose jobs to firms relocating overseas. We examine offshoring of final retail and merchandising goods in the 19501980 period, manufactured goods (intermediate goods) in the 1970-2000 period, and current service sector and high-skilled jobs. The impacts of offshoring vary considerably over these time periods. Most notably, when offshoring occurs in high-skilled industries such as computer software and bioengineering, the contributions to economic growth will be smaller compared to the retail and manufacturing experiences over the last 60 years. The results also show wage and per household income effects.
\end{abstract}

\section{Keywords}

Service Offshoring, Wage Inequality, Income Distribution

\section{Introduction}

The impact of offshoring on the US economy does not appear to be large, but a closer look at the city level reveals important impacts. We use a city-level computable general equilibrium (CGE) model to analyze three periods of offshoring over the last 60 years in the US and their effects on city-level characteristics such as employment, distribution of wages and household income, labor absorption and local tax revenue. The first offshoring period occurred in the final retail and merchandising industry during 1950-1980. (Offshoring also occurred in other sectors in this period as [1] asserted that information technology (IT) offshoring began in 1949 with ADP and payroll processing; however, [1] stated that IT offshoring on a large scale is from a 1990 decision by Eastman-Kodak to outsource most of their IT functions.) The second period of offshoring involved a wide range of manufacturing goods used as intermediate inputs which began in 1970-2000. The third and current period of offshoring is occurring in services, such as legal and medical services, and in high-wage industries, such 
as computer software and bioengineering. A fourth offshoring period, the offshoring of individual tasks proposed by [2], is not considered.

This paper adds valuable insights to the current offshoring literature as it estimates the benefits of the first three periods of offshoring for US cities that did not experience any direct job loss from firms moving overseas. Other studies have analyzed the impacts of offshoring from a either firm or aggregate level (see [3] for review), but these perspectives may not be relevant for all cities as the production of final retail goods occurred mostly in the eastern part of the US, so when these production processes moved to Japan and the NIES countries (Taiwan, Singapore, South Korea and Hong Kong) many US cities simply benefited from lower final retail prices without suffering job loss of these firms moving overseas. Also, the locations of manufacturing firms in the 1970s were primarily located in the eastern and Midwestern parts of the US allowing the rest of the US to benefit from lower-priced intermediate manufactured goods. Currently, sectors such as legal and medical are starting to use overseas services to lower prices of the final services produced in the US. These legal and medical sectors are primarily located in large urban centers [4] who can then offer these services at lower prices to medium and small urban areas in the US. Bioengineering is a new US sector that is primarily produced domestically. We will also explore the potential impacts of this sector eventually offshoring some of its production.

The CGE model is based on utility and profit maximization principles, and represents multiple commercial sectors, household groups (distinguished by income), a variety of labor supply decisions and several types of taxes paid to the local government. An important advantage of a CGE model is that lower import prices will impact household demand and the intermediate input mix used by many sectors. Both of these channels have important effects on understanding the economic impacts of offshoring.

Our results show that the offshoring of manufactured goods had the largest effect due to the relative importance of manufactured goods used as intermediate inputs by many sectors in the economy. Offshoring of retail goods had the second largest impact due to its relative importance in the household expenditure patterns. High services had the third largest impact while the potential impact of offshoring bioengineering has the smallest impact. Our results also show important wage and household income effects.

\section{Offshoring History and Literature}

With regards to the three periods of offshoring, reference [5] argues that the first period of offshoring final retail and merchandising goods started in the early 1960s with the initial destination being Columbia and South America, but due to economic and political instability, trade unions and exchange uncertainty, production moved to East Asia and was soon a global occurrence [6]. The world export share of merchandise and manufacturing has doubled and quadrupled respectively since 1950 with many developing economies increasing their export share [7]. The second period of offshoring focused on manufacturing goods that were primarily used as intermediate inputs. From 1987 to 1997, the import share of inputs in US manufacturing increased from $10.5 \%$ to $16.2 \%$ and from $26 \%$ to $38 \%$ for high-wage manufacturing such as computers and electronics [8]. The third and current period of offshoring involves services and high-skilled jobs. While the advances in technology are a key component to service offshoring, reference [9] states that the business community had to change its perspective on services from a local production activity to a "replicable commodity". They state that this began in earnest in the late 1980s and early 1990s.

With regards to the effects of offshoring on regional characteristics, [10] constructs a two sector general equilibrium model and finds limited aggregate employment effects of offshoring. Reference [11] develops a theoretical two-sector specific sector model and finds that when the offshored factor is also produced domestically the net effect on workers is ambiguous, but capital gains unambiguously and the overall economy expands. Reference [12] found that in countries with flexible labor markets, such as the United States, an increase in manufacturing offshoring resulted in an increase in wage inequality. Reference [13] disaggregated labor into three categories and found that an increase in manufacturing offshoring shifted away from the unskilled and into medium and high skilled workers. Reference [9] also found that service offshoring increases demand for high-skilled labor while reducing medium- and low-skilled labor.

Another aspect of the work on offshoring is the way in which offshoring shocks are transmitted through an economy. References [14] and [15] have looked at two-sector models to understand the role of vertical fragmentation in a variety of sectors. Reference [16] examines two transmission mechanisms that can explain how an offshoring shock can impact an economy. First, input-output linkages are identified for many two-digit Aus- 
trian manufacturing industries, so that when a sector-specific offshoring shock occurs, the effects can be traced throughout the entire economy. A second transmission mechanism focuses on the labor supply effect where displaced labor attempts to find employment in other sectors in the economy. They claim that when these transmission mechanisms are taken into account, more accurate impacts of offshoring can be obtained. Our CGE model is comprehensive enough to evaluate these transmission mechanisms.

\section{The Computable General Equilibrium (CGE) Model}

This section provides an overview and intuitive description of the CGE model. For a full detailed presentation of the model and data collected see [17] or [18]. We use a city-level CGE model, based on 1996 data from Fort Collins, Colorado. Fort Collins is a medium-sized city that compares to the description of standard mediumsized cities in [4] as a regional service center with a population between 100,000 and 500,000, and a primary export base of traditional manufacturing and/or high-wage services (regional finance, education, etc.). CGE models offer a perspective on an economy that is difficult to duplicate using an econometric model or a general equilibrium (GE) technique. CGE models can account for the relative importance of intermediate inputs, factor demand (labor, capital and land), tax payments and imports as they contribute to domestic supply. These components reflect most of the important ways in which an offshoring shock is transmitted through an economy as argued by [14]. An econometric model would have to be based on an enormous amount of data to capture these aspects of an economy in one model, which is not typically seen. A GE model becomes mathematically intractable with such a detailed description of the economy used in CGE analysis. A CGE model can bridge the gap between standard GE models and econometric approaches by combining modeling assumptions of GE models and the size of elasticities estimated in the econometric literature.

A CGE model captures the interaction between households, the private sector, the local government and the city economy. See Figure 1 for the structure of the system. Firms or sectors maximize profits and households

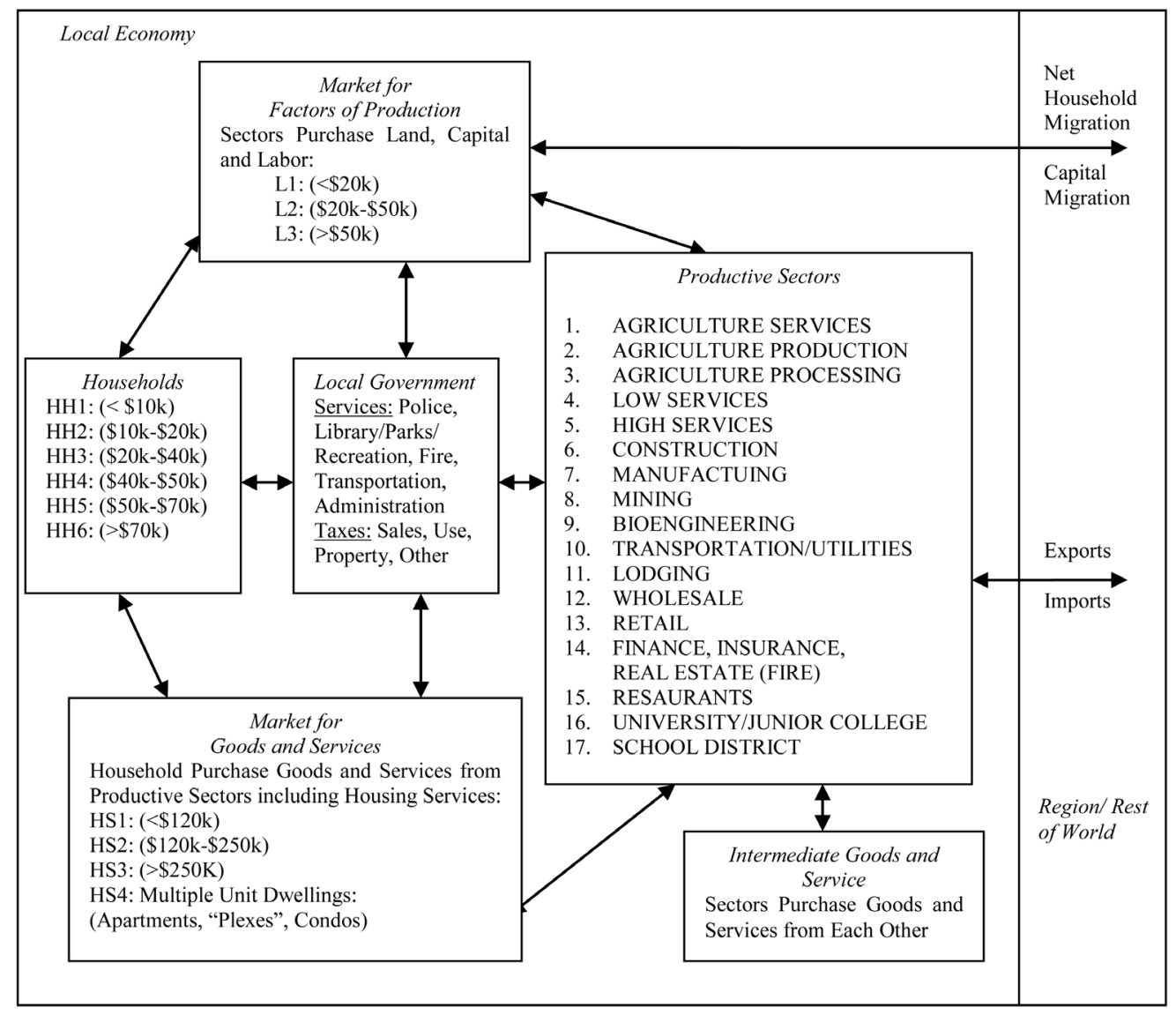

Figure 1. Structure of the system. 
maximize utility as both groups make economic decisions. Sectors purchase three types of labor, physical capital and land. Sectors also purchase an array of intermediate inputs and pay sales, use and property taxes. These sectors also import and export goods. Households purchase goods and services from the sectors and also pay an array of taxes as well. The city government is constrained to have a balanced budget restricting the amount of government expenditures by the amount of tax revenue collected.

The data collected for firms, households and government are organized in a social accounting matrix (SAM). A SAM is constructed so it links all the data in a way that reflects how the different components of economy interacts (see [19] for a detailed discussion). The CGE model is "calibrated" when the equations in the model can exactly reproduce the data in the SAM. After calibration, the CGE model can be used to perform simulations by changing exogenous variables such as import prices to see how the level and distribution of economic activity is impacted.

\section{Simulation Setup and Results}

This section describes how the simulations are setup that are used to model the economic impact of the offshoring of final retail and merchandising goods in the 1950-1980 period, manufactured goods in the 1970-2000 period and high skilled jobs that is occurring presently. The next section presents the results of the analysis.

\subsection{Simulation Setup}

The offshoring effect is examined separately for retail, manufacturing, high services and bioengineering. This effect is modeled by lowering the import price by $5 \%$ for each of the four sectors separately. Lower import prices across these four sectors are transmitted through the economy differently which accounts for varying economic outcomes across simulations. For example, lower retail import prices causes the price of retail goods to fall and since retail purchases are the largest component in the consumption function (Table 1), the city CPI falls which leads to positive real income effects for consumers. Retail goods play a relatively small role in the supply of intermediate inputs (Table 1) so this transmission mechanism is small. We maintain that most cities, large and small would have the same basic characteristics with respect to retail, so the effects in this paper should be general for most cities or regions.

However, as Table 1 indicates, manufactured goods account for approximately $34 \%$ of all intermediate inputs used in the city economy, so lower import prices will positively affect all the sectors that rely on intermediate

Table 1. Characteristics and intermediate inputs.

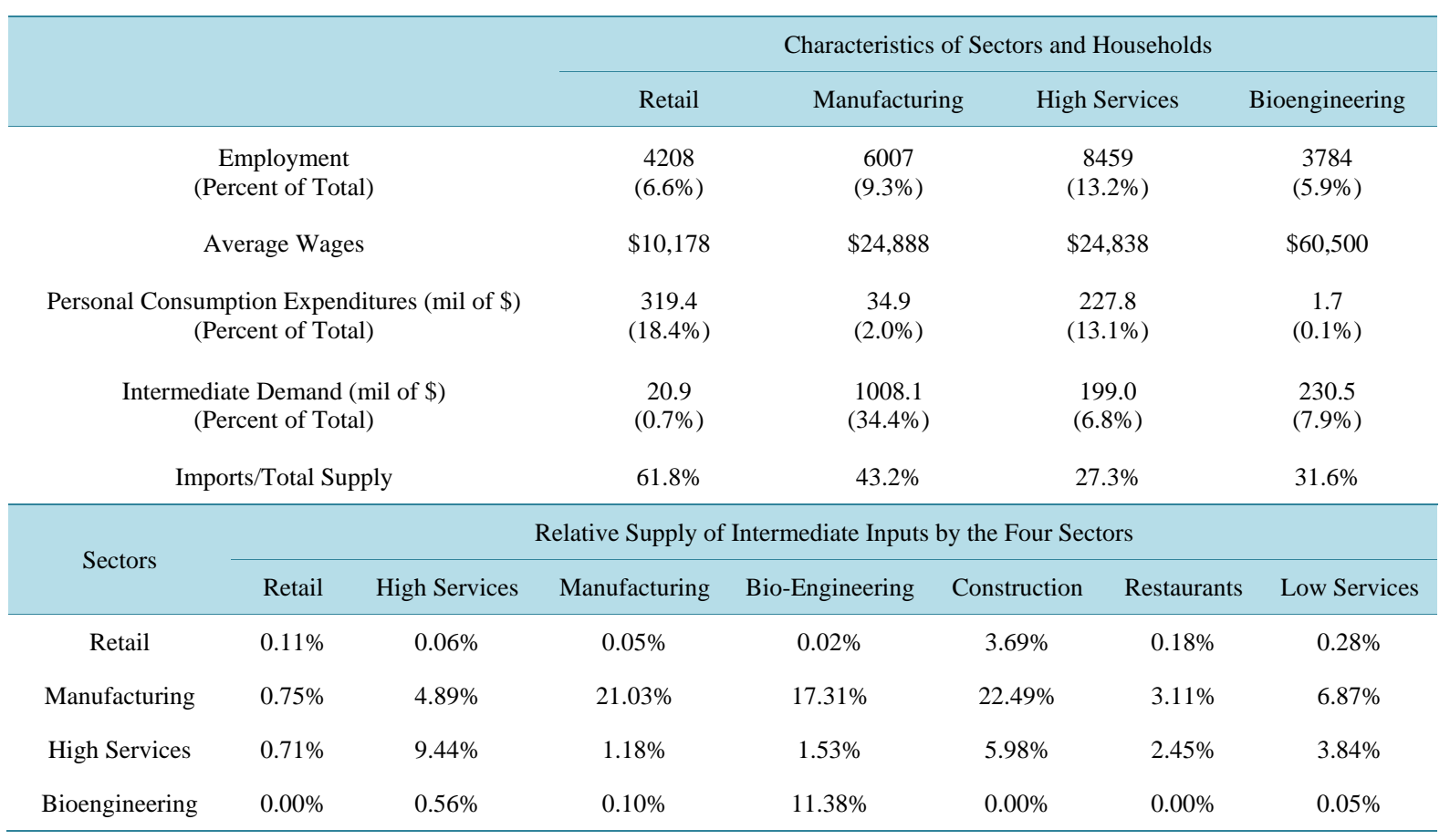


manufactured inputs. Table 1 indicates that consumers purchase a relatively small amount of manufactured goods so the impact through the use of intermediate inputs will be the way the economy is affected by lower import prices for manufactured goods. The importance of manufacturing goods used as intermediate inputs may vary across cities so the size of this result could vary.

The high services sector makes up approximately $13 \%$ of the household consumption budget so it is similar to retail but does account for $6.8 \%$ of intermediate inputs used. Therefore, sectors that use high services as an intermediate input will benefit from lower prices. Lower import prices for high services will impact the economy through household consumption and the use as an intermediate input.

The bioengineering sector is not directly consumed by households but its use as an intermediate input is approximately $8 \%$. When we collected the data for our model, the bioengineering was called computer manufacturing. This sector has similar characteristics to bioengineering and medical equipment since it is not consumed directly by consumers, its use as an input is focused just on its own sector and its wage income is relatively high. We feel that these characteristics are similar enough for simulations to represent rough estimates of the future impacts of offshoring bioengineering.

\subsection{Results}

Table 2 and Table 3 present the results of a five percent decline in import prices separately for each of the four sectors. The largest economic impact in terms of employment, city tax revenue and real household income occurs in the manufacturing case or the second period of offshoring. Given that manufacturing plays a small part in household consumption, the only channel of importance is the intermediate input component as manufacturing supplies $34.4 \%$ of all intermediate inputs in the economy. Besides the expansion of the manufacturing sector, other sectors such as construction, bioengineering, low services and high services that rely on manufactured goods as inputs grow. Reference [20] demonstrates econometrically that when costs of supplying intermediate

Table 2. The offshoring effect.

\begin{tabular}{|c|c|c|c|c|c|c|c|c|}
\hline & \multicolumn{2}{|c|}{ Retail } & \multicolumn{2}{|c|}{ Manufacturing } & \multicolumn{2}{|c|}{ High Services } & \multicolumn{2}{|c|}{ Bioengineering } \\
\hline & Amount & Change & Amount & Change & Amount & Change & Amount & Change \\
\hline Employment & 679 & $1.1 \%$ & 853 & $1.33 \%$ & 454 & $0.71 \%$ & 119 & $0.18 \%$ \\
\hline Tax Revenue (mil of \$) & $\$ 1.20$ & $1.4 \%$ & $\$ 2.96$ & $3.4 \%$ & $\$ 0.78$ & $0.9 \%$ & $\$ 0.39$ & $0.4 \%$ \\
\hline CPI & & $-0.69 \%$ & & $-0.04 \%$ & & $-0.30 \%$ & & $0.01 \%$ \\
\hline \multicolumn{9}{|l|}{ Real Wages } \\
\hline L1 & & $0.42 \%$ & & $0.55 \%$ & & $0.15 \%$ & & $0.01 \%$ \\
\hline L3 & & $0.28 \%$ & & $0.34 \%$ & & $0.18 \%$ & & $0.04 \%$ \\
\hline \multirow[t]{2}{*}{ L3 } & & $0.37 \%$ & & $0.41 \%$ & & $0.24 \%$ & & $0.15 \%$ \\
\hline & \multicolumn{8}{|c|}{ Total Real Household Income (millions of \$) } \\
\hline \multirow[t]{2}{*}{ Change } & $\$ 21.38$ & $1.3 \%$ & $\$ 24.87$ & $1.5 \%$ & $\$ 12.20$ & $0.7 \%$ & $\$ 3.96$ & $0.2 \%$ \\
\hline & \multicolumn{8}{|c|}{ Per Household Real Income (in \$) } \\
\hline Household Category & Change & Percent & Change & Percent & Change & Percent & Change & Percent \\
\hline HH1 & $\$ 14.32$ & $0.27 \%$ & $\$ 55.80$ & $1.04 \%$ & $\$ 29.69$ & $0.55 \%$ & $\$ 6.19$ & $0.12 \%$ \\
\hline HH2 & $\$ 97.50$ & $0.48 \%$ & $\$ 113.24$ & $0.56 \%$ & $\$ 53.58$ & $0.27 \%$ & $\$ 8.08$ & $0.04 \%$ \\
\hline HH3 & $\$ 119.86$ & $0.40 \%$ & $\$ 221.79$ & $0.74 \%$ & $\$ 99.70$ & $0.33 \%$ & $\$ 32.15$ & $0.11 \%$ \\
\hline $\mathrm{HH} 4$ & $\$ 305.65$ & $0.72 \%$ & $\$ 253.84$ & $0.60 \%$ & $\$ 146.91$ & $0.35 \%$ & $\$ 33.22$ & $0.08 \%$ \\
\hline HH5 & $\$ 282.47$ & $0.69 \%$ & $\$ 305.50$ & $0.75 \%$ & $\$ 144.18$ & $0.36 \%$ & $\$ 36.59$ & $0.09 \%$ \\
\hline HH6 & $\$ 531.21$ & $0.74 \%$ & $\$ 830.34$ & $1.15 \%$ & $\$ 306.62$ & $0.43 \%$ & $\$ 173.70$ & $0.24 \%$ \\
\hline
\end{tabular}


Table 3. The employment effect for selected sectors.

\begin{tabular}{ccccc}
\hline \multirow{2}{*}{ Sectors } & \multicolumn{4}{c}{ Relative Supply of Intermediate Inputs by the Four Sectors } \\
\cline { 2 - 5 } & Retail & High Services & Manufacturing & Bioengineering \\
\hline Construction & 100 & 232 & 69 & 18 \\
Manufacturing & 18 & 163 & 13 & 0 \\
Bioengineering & 9 & 50 & 6 & 38 \\
Retail & 124 & 37 & 32 & 7 \\
FIRE & 45 & 27 & 30 & 4 \\
Lodging & 2 & -1 & 2 & 0 \\
Restaurants & 50 & 37 & 33 & 6 \\
Low Services & 112 & 134 & 79 & 12 \\
High Services & 70 & 58 & 95 & 103 \\
Total & 314 & 501 & 177 & \\
\hline
\end{tabular}

inputs abroad falls, the percentage of US inputs used for domestic production falls; however, given the limitation of data, is unable to capture how the lower input prices affect the service and retail sectors, and how the lower prices could impact the general price level and potential real income effects.

The retail simulation leads to the second largest economic gain in household income due to its importance in the consumption budget. The $5 \%$ decrease in retail import prices leads to a fall in the city CPI of $0.69 \%$, which causes positive real income effects and total real household income grows by $1.3 \%$. Given that most cities and regions did not manufacture retail goods, the economic gains for most of the country were considerable due the first period of offshoring final retail goods during the 1950-1980 period.

The high services sector causes the third largest increase in household income. This sector is the second most important in element in consumption and does supply $6.8 \%$ of intermediate inputs supplied in the local economy. A factor that offsets the impact of this simulation is that the amount of imports were relatively small for this sector so the $5 \%$ fall in import prices operated off a smaller base. The bioengineering sector plays a small role in intermediate supply and in local consumption so it has a negligible price effect and relatively no impact on the economy.

Table 2 also presents results for the impact on the distribution of real wages and per household real income. It is these results that highlight the value of a CGE model. The retail and manufacturing cases caused higher wage growth rates for low-wages workers (L1) compared to medium- and high-wage workers (L2 and L3), though the magnitude of these results are small. While, both cases start to reduce wage inequality, they do for different reasons.

It is the case that the construction and low services sectors use a relatively large amount of manufacturing intermediate inputs and expand more than other sectors in the economy. This is seen in Table 3 which presents the employment effects for selected sectors. Since construction and low services employ a relatively large number of low wage workers, the total expansion in employment favors L1 and thus sees a larger increase in real wages for L1. For the retail case, it is the retail, construction and low services sectors that see the largest employment gains and since these sectors employ relatively more L1 workers, real wages rise more for this group.

These results differ from [12] and [13] who found evidence for wage inequality in these cases. The ability of the CGE model to isolate these shocks reveals that their aggregate results may not apply to all cities and, in fact, cities that did not experience any direct job loss from offshoring may experience the exact opposite impact on wage inequality. With regards to the high services and bioengineering offshoring, our results are consistent with [12] who find that service offshoring increases wage inequality.

Reference [21] demonstrates econometrically that offshoring increases the relative wage of nonproduction workers at the expense of production workers but is unable to draw conclusions of the impact on the distribution of household income and the ability of a city to collect taxes and supply city services. Our CGE model is comprehensive enough to evaluate these transmission mechanisms. 
A broader measure of welfare is household income which includes capital and land income along with labor income. The bottom panel of Table 2 presents the results for the distribution of per household real income. The manufacturing case reveals interesting results. Consistent with the real wage effects, HH1 sees a relatively large percentage increase in per household income since many L1 workers reside in HH1. However, HH6 (income greater than \$70,000) sees the largest increase in per household income (absolute and percentage terms). Since HH6 owns the largest percentage of capital and land in the economy, the expansion of the economy leads to gains in capital and land income which is funneled to HH6. The retail case reveals that HH1 sees the smallest gain in per household income even though L1 had the largest increase in real wages. This is due to the fact that the majority of capital and land income is earned by households HH4-HH6. These amounts are large enough to offset the impacts the real wage effects. For the high services and bioengineering cases, there is no meaningful change in the distribution of real household income.

In summary, our results indicate that examining real per household income provides a more complete picture of the effects of offshoring than just examining real wages. Real wage effects do not always coincide with real household income effects as our analysis indicates. Whereas [12] and [13] focused on the impact on real wages, our analysis permits an examination of a broader measure of household welfare.

\section{Conclusions}

This paper investigated the impacts of offshoring final goods in retail in the 1960-1980 period and intermediate manufacturing inputs that occurred primarily in the 1970-2000 period. The more current phenomenon of offshoring high services such as medical and legal services and high-wage industries such as bioengineering and other high-end research was also examined. A data-intensive CGE model was used which is flexible enough to examine all of these scenarios.

We can get a sense of the differences in the pure effects of offshoring shocks over the last 50 years for regions that did not lose jobs directly. The first two periods of offshoring in final retail/merchandise and intermediate manufacturing goods led to the largest amount of growth. The lower import prices for retail goods were transmitted through the consumption channel while offshoring in manufacturing goods was transmitted through the input-output linkage. The retail and manufacturing cases reduce wage inequality whereas high services and bioengineering increase wage inequality, though examining real per household income provides a more complete picture of the effects of offshoring.

The more recent evolution of offshoring high services will lead to a smaller stimulus to economic activity which might contribute to slower economic growth in the future. Finally, as the US economy transitions to more high paying jobs such as bioengineering, any offshoring that will occur will have small and possibly imperceptible effects on economic activity.

\section{References}

[1] Applegate, L.M., McFarlan, F.W. and McKenney, J.L. (1996) Corporate Information Systems Management. Irwin, Chicago.

[2] Grossman, G. and Rossi-Hansberg, E. (2008) Trading Tasks: A Simple Theory of Offshoring. American Economic Review, 98, 1978-1997. http://dx.doi.org/10.1257/aer.98.5.1978

[3] Olsen, K.B. (2006) Productivity Impacts of Offshoring and Outsourcing: A Review. OECD STI Working Paper 2006/1, OECD Directorate for Science, Technology and Industry, Paris.

[4] Henderson, J.V. (1997) Medium Size Cities. Regional Science and Urban Economics, 27, 583-612. http://dx.doi.org/10.1016/S0166-0462(96)02169-2

[5] Jones, R., Kierzkowski, H. and Lurong, C. (2005) What Does Evidence Tell Us about Fragmentation and Offshoring? International Review of Economics and Finance, 14, 305-316. http://dx.doi.org/10.1016/j.iref.2004.12.010

[6] Morawetz, D. (1977) Twenty-Five Years of Economic Development: 1950-1975. World Bank, Washington DC.

[7] Hummels, D.L., Rapoport, D. and Yi, K. (1998) Vertical Specialization and the Changing Nature of World Trade. Economic Policy Review, 4, 77-99.

[8] Bardhan, A.D., Jaffee, D.M. and Kroll, C.A. (2004) Globalization and a High-Tech Economy. Kluwer Academic Publishers, Boston.

[9] Metters, R. and Verma, R. (2008) History of Offshoring Knowledge Services. Journal of Operations Management, 26, 141-147. http://dx.doi.org/10.1016/j.jom.2007.02.012 
[10] Mitra, D. and Ranjan, P. (2010) Offshoring and Unemployment: The Role of Search Frictions Labor Mobility. Journal of International Economics, 81, 219-229. http://dx.doi.org/10.1016/j.jinteco.2010.04.001

[11] Barta, R. and Beladi, H. (2010) A Simple Two-Sector Model of Outsourcing. Review of Development Economics, 14, 64-73.

[12] Crinò, R. (2009) Offshoring, Multinationals and Labour Market: A Review of the Empirical Literature. Journal of Economic Surveys, 23, 197-249. http://dx.doi.org/10.1111/j.1467-6419.2008.00561.x

[13] Hijzen, A., Gorg, H. and Hine, R.C. (2005) International Offshoring and the Skill Structure of Labour Demand in the United Kingdom. The Economic Journal, 115, 860-878. http://dx.doi.org/10.1111/j.1468-0297.2005.01022.x

[14] Grossman, G.M. and Helpman, E. (2002) Integration versus Offshoring in Industry Equilibrium. Quarterly Journal of Economics, 117, 85-120. http://dx.doi.org/10.1162/003355302753399454

[15] Egger, H. and Falkinger, J. (2003) The Role of Public Infrastructure and Subsidies for Firm Location and International Outsourcing. European Economic Review, 50, 1993-2015. http://dx.doi.org/10.1016/j.euroecorev.2005.10.002

[16] Egger, H. and Egger, P. (2005) Labor Market Effects of Offshoring under Industrial Interdependence. International Review of Economics and Finance, 14, 349-363. http://dx.doi.org/10.1016/j.iref.2004.12.006

[17] Cutler, H. and Davies, S. (2007) The Impact of Specific-Sector Changes in Employment of Economic Growth, Labor Market Performance and Migration. Journal of Regional Science, 47, 935-963. http://dx.doi.org/10.1111/j.1467-9787.2007.00537.x

[18] Burnett, P. (2012) Urban Industrial Composition and the Spatial Expansion of Cities. Land Economics, 88, 764-781.

[19] Schwarm, W. and Cutler, H. (2003) Building Small City and Town SAMs and CGE Models. Review of Urban and Regional Development Studies, 15, 132-147.

[20] Swenson, D.L. (2005) Overseas Assembly and Country Sourcing Choices. Journal of International Economics, 66, 107-130. http://dx.doi.org/10.1016/j.jinteco.2004.07.005

[21] Feenstra, R.C. and Hanson, G.H. (1999) The Impact of Offshoring and High-Technology Capital on Wages: Estimates for the United States, 1979-1990. Quarterly Journal of Economics, 114, 907-940. http://dx.doi.org/10.1162/003355399556179 
Scientific Research Publishing (SCIRP) is one of the largest Open Access journal publishers. It is currently publishing more than 200 open access, online, peer-reviewed journals covering a wide range of academic disciplines. SCIRP serves the worldwide academic communities and contributes to the progress and application of science with its publication.

Other selected journals from SCIRP are listed as below. Submit your manuscript to us via either submit@scirp.org or Online Submission Portal.
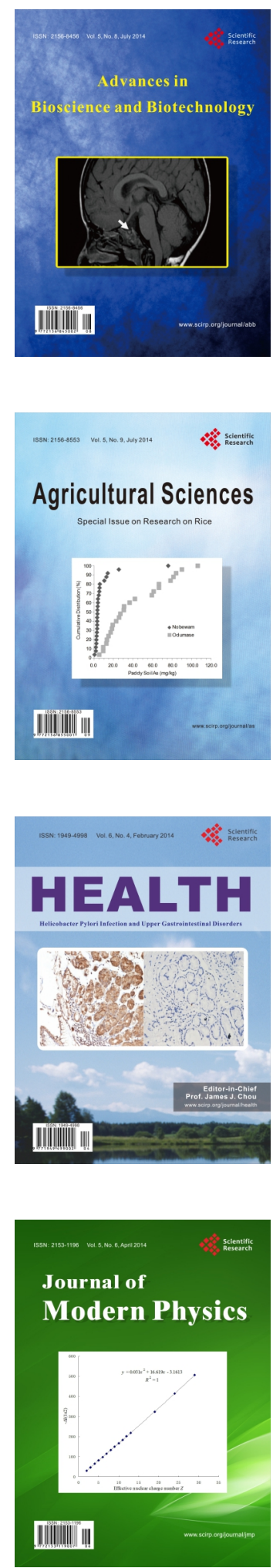
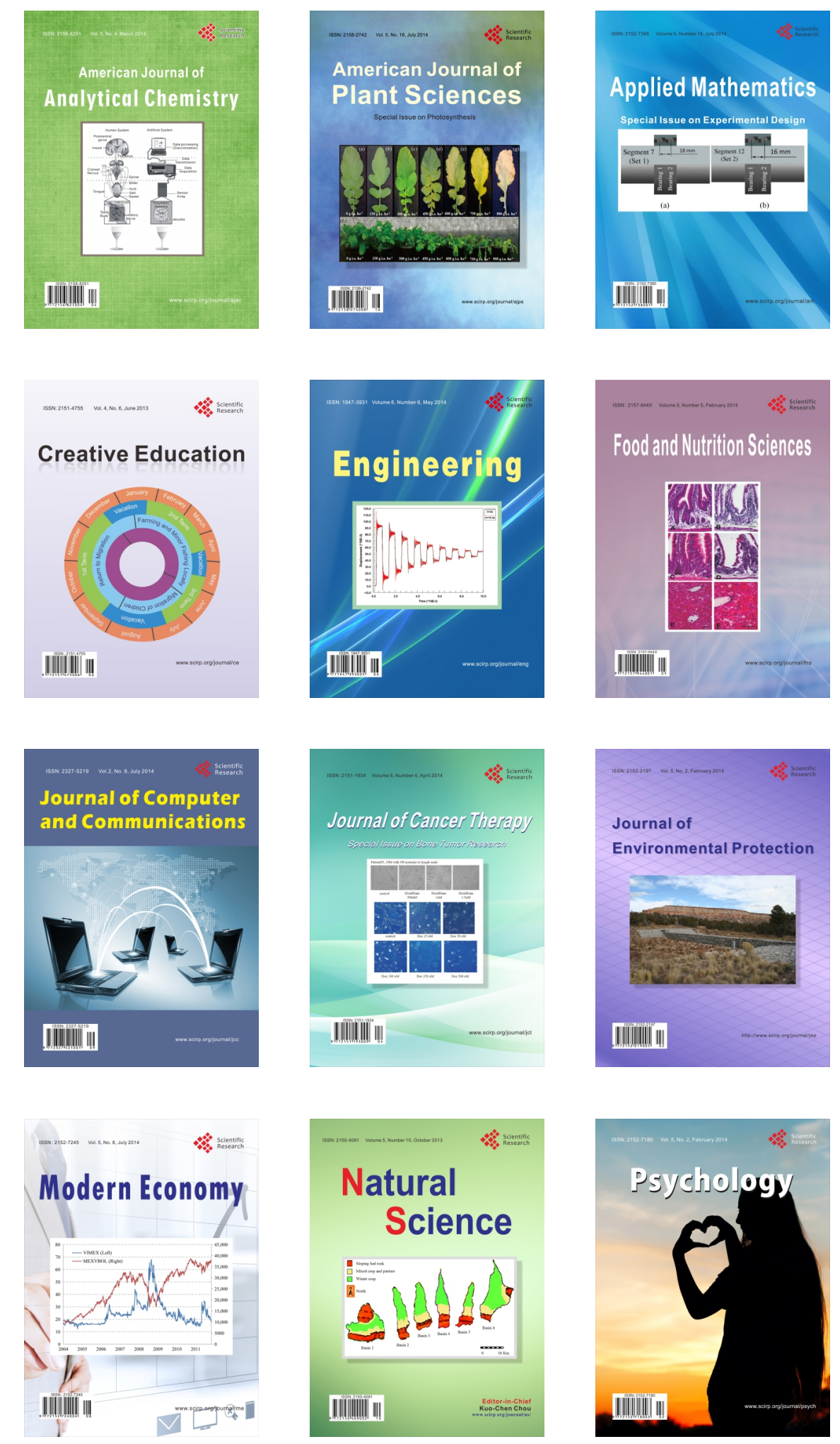